\section{PENGEMBANGAN BAHAN AJAR MATA KULIAH DASAR-DASAR \\ DESAIN BERBASIS KEARIFAN LOKAL BAGI MAHASISWA \\ PENDIDIKAN SENI RUPA}

Eni Puji Astuti dan Ismadi

FBS Universitas Negeri Yogyakarta

email: enipa.anipa@gmail.com

\section{Abstrak}

Penelitian ini bertujuan untuk mengembangkan bahan ajar berupa modul Mata Kuliah Dasar-dasar Desain Seni Kerajinan berbasis kearifan lokal bagi mahasiswa Pendidikan Seni Rupa FBS, UNY. Pada penelitian ini dikembangkan produk bahan ajar berupa modul cetak. Metode yang digunakan dalam penelitian ini adalah pengembangan (Research and Development) dengan langkah-langkah yang telah dilaksanakan meliputi analisis kebutuhan bahan ajar melalui kegiatan Focus Group Discussion, pengembangan produk, uji ahli yang meliputi ahli materi dan ahli media, uji pengguna terbatas dan refisi. Data dianalisis dengan menggunakan analisis deskriptif kuantitatif teknik prosentase dan kualitatif. Hasi uji ahli dari komponen kelayakan isi mencapai skor rerata penilaian 90\%, komponen penyajian $95 \%$ dan komponen tampilan90,6\%. Hasil uji pengguna terbatas mencapai skor rereta penilaian dari komponen tampilan $92,5 \%$ dan komponen tampilan 95\%. Hal tersebut menunjukkan bahwa modul dinilai baik dan layak dijadikan sebagai bahan ajar pendukung pembelajaran Dasar-dasar Desain di Jurusan Pendidikan Seni Rupa.

Kata kunci: modul, dasar-dasar desain

Abstract

This research aims at developing the teaching material in the form of lecture notes for The Basic Principles of Craft Designs based on local wisdom for students of Fine Arts Education Study Program, Yogyakarta State University. In this research the teaching material is developed in the form of printed material. The method used in this research is research and development method by conducting certain steps including the analysis of teaching material needs through Focus Group Discussion, product development, expert judgment conducted by experts in the related material and in media, limited-user testing, and revision. The data were analyzed by using quantitative-descriptive analysis with percentage technique and descriptive qualitative technique. The testing result shows that the mean score of the component feasibility is $90 \%$; the mean score of the serving feasibility is $95 \%$; and that of the appearance feasibility is $90.6 \%$. The limited-user testing reaches the score of $92.5 \%$ for the serving component and $95 \%$ for the appearance component. This shows that the printed material is considered good and proper to be an additional material for the course of the Basic Principles of Craft Designs in Fine Arts Education Study Program.

Keywords: modules, the basic principles of design

\section{PENDAHULUAN}

Mata Kuliah Dasar-dasar Desain Seni Kerajinan dalam kurikulum di Jurusan Pendidikan Seni Rupa merupakan mata kuliah dasar yang diberikan pada mahasiswa untuk mendukung mata kuliah seni kerajinan. Tujuan dari mata kuliah ini adalah agar mahasiswa memahami tentang Dasar-dasar Desain Seni Kerajinan baik sejarah dan aplikasinya, mampu membuat konsep karya desain kerajinan dan memiliki kemampuan mengembangkannya dalam kompetensinya sebagai pendidik.

Karakteristik Program Studi Seni Kerajinan memiliki keunikan dalam menjaga dan mengembangkan karya seni kerajinan yang telah menjadi warisan budaya leluhur. Desain yang dikembangkan di program studi ini meliputi desain batik, keramik, kerajinan kayu, kerajinan kulit dan kerajinan logam. Materi-materi pembelajaran bidang seni kerajinan memiliki keterkaitan dengan persoalan lingkungan, budaya dan artefak hasil budayanya. Untuk itu perlu dikembangkan sebuah perangkat pembelajaran yang mampu memfasilitasi hal tersebut.

Berdasarkan pengalaman mengajar selama ini, minat mahasiswa dalam mata kuliah ini cukup tinggi dengan beragamnya model dan media pembelajaran yang telah diterapkan oleh dosen. Namun demikian ada beberapa hal yang menjadi kendala peningkatan kompetensi mahasiswa antara lain: 1) keterbatasan sumber belajar atau literatur tentang Dasar-dasar Desain Seni Kerajinan berupa buku teks, 2) minat baca mahasiswa yang masih rendah sehingga mahasiswa masih memiliki ketergantungan dengan instruksi dosen secara langsung dalam kegiatan pembelajaran, 3) mahasiswa membutuhkan bahan ajar yang dapat dikembangkan untuk tujuan mengajar di sekolah, 4) masih terbatasnya sumber belajar tenang aplikasi kearifan lokal dalam karya desain. Untuk itu diperlukan perangkat pembelajaran yang dapat mengatasi kendala tersebut berupa bahan ajar yang memiliki karakter mengembangkan kearifan lokal yang aplikatif.

Pada tingkat pendidikan tinggi, bahan ajar seharusnya dapat menjadi alat eksplorasi bagi mahasiswa untuk mengembangkan diri, membangun kepekaan terhadap lingkungan dan menginspirasi mereka dalam mengatasi persoalan di lingkungannya. Buku teks tentang Dasar-dasar Desain Seni Kerajinan selama ini sangat terbatas jenis dan jumlahnya terlebih lagi buku yang secara sistematis sesuai dengan tujuan dari pembelajaran Dasar-dasar Desain itu sendiri. Untuk 
itulah diperlukan bahan ajar yang dapat menjembatani keterbatasan yang ada yaitu modul pembelajaran berbasis kearifan lokal yang tertuang di dalamnya.

Modul merupakan salah satu jenis bahan ajar yang relatif lengkap yaitu meliputi isi materi, metode dan evaluasi yang dilakukan secara mandiri. Sistem belajar dengan fasilitas modul telah dikembangkan baik di luar maupun didalam negeri, yang dikenal dengan Sistem Belajar Bermodul (SBB). SBB telah dikembangkan dalam berbagai bentuk dengan berbagai nama pula, seperti Individualized Study System, Self-pased study course, dan Keller plan (Tjipto Utomo dan Kees Ruijter,1990). Modul secara eksplisit dan sistematis dapat memuat karakter dari pembelajaran sehingga sangat memungkinkan diterapkannya kearifan lokal dalam unsur-unsur di dalamnya. Pengembangan bahan ajar berupa modul yang berbasis kearifan lokal diharapkan dapat mengatas kendala yang selama ini ada sebab di dalam modul memungkinkan adanya kelengkapan mulai dari strategi, materi, penugasan dan evaluasinya. Mahasiswa juga dapat belajar secara mandiri dan dapat belajar lebih aktif serta dapat mengatasi perbedaan kemampuan antar mahasiswa sehingga pembelajaran dapat berjalan lebih efektif dan efisien.

Sejalan dengan paparan diatas, peneliti menilai pentingnya pengembangan bahan ajar berupa modul pembelajaran berbasis kearifan lokal in segera diwujudkan yang harapannya hasil pengembangannya dapat segera diterapkan, terlebih lagi saat ini pendidikan karakter bangsa sedang gencar didengungkan.

Berdasarkan latar belakang yang telah diuraikan di atas, peningkatan kualitas pembelajaran perlu didukung dengan pengembangan kelengkapan bahan ajar sehingga permasalahan yang akan dijawab dalam penelitian ini adalah bagaimana mengembangkan modul mata kuliah Dasar-dasar Desain Seni Kerajinan berbasis kearifan lokal bagi Mahasiswa Pendidikan Seni Rupa. Selanjutnya, dihasilkan produk bahan ajar berupa modul Mata Kuliah Dasar-dasar Desain Seni Kerajinan bagi Mahasiswa Pendidikan Seni Rupa FBS UNY.

\section{KAJIAN TEORI}

\section{Mata Kuliah Dasar-dasar Desain}

Mata Kuliah Dasar-dasar Desain Seni Kerajinan dalam kurikulum di Jurusan Pendidikan Seni Rupa merupakan mata kuliah dasar yang diberikan pada mahasiswa di tahun pertama perkuliahan. Mata Kuliah ini memiliki tujuan agar mahasiswa memahami sejarah dan filosofi Dasar-dasar Desain Seni Kerajinan Nusantara, memahami dan menerapkan unsur-unsur desain dengan menggunakan prinsip desain, mampu mengembangkan konsep karya desain kerajinan dan memiliki kemampuan dalam mengajarkan teknik Dasar-dasar Desain Sen Kerajinan di sekolah.
Dasar-dasar Desain Seni Kerajinan merupakan mata kuliah praktek kode MK SRK 343 dengan beban kuliah 3 SKS yang juga merupakan mata kuliah commond ground di dua program studi yaitu program studi Pendidikan Seni Rupa dan Program Studi Seni Kerajinan. Karakter dasar-dasar desain pada mata kuliah commond ground ini disesuaikan dengan bidang keahlian masing-masing prodi, dan prodi Pendidikan Seni Kerajinan lebih menonjolkan kemampuannya dalam desain produk seni kerajinan.

\section{Bahan Ajar Modul}

Modul adalah bahan ajar yang disusun secara sistematis dan menarik yang mencakup isi materi, metoda, dan evaluasi yang dapat digunakan secara mandiri. Pembelajaran dengan modul adalah pendekatan pembelajaran mandiri yang berfokuskan penguasaan kompetensi dari bahan kajian yang dipelajari peserta didik dengan waktu tertentu sesuai dengan potensi dan kondisinya.

Sebuah modul bisa dikatakan baik dan menarik apabila terdapat karakteristik sebagai berikut (Vembriarto, 1985: 27). 1. Self Instructional; yaitu melalui modul tersebut seseorang atau peserta belajar mampu membelajarkan diri sendiri, tidak tergantung pada pihak lain. Untuk memenuhi karakter self instructional, maka dalam modul harus berisi tujuan pembelajaran, materi pembelajaran yang disusun spesifik untuk memudahkan belajar, disertai contoh dan ilustrasi, menampilkan soal, tugas dan pengukuran tingkat penguasaan lain, kontekstual, bahasanya dapat dimengerti dengan mudah dan terdapat rangkuman materi pembelajaran, instrument penilaian, umpan balik dan referensi. 2. Self Contained; yaitu seluruh materi pembelajaran dari satu unit kompetensi atau sub kompetensi yang dipelajari terdapat di dalam satu modul secara utuh. Tujuan dari konsep ini adalah memberikan kesempatan pembelajar mempelajari materi pembelajaran yang tuntas, karena materi dikemas ke dalam satu kesatuan yang utuh. Jika harus dilakukan pembagian atau pemisahan materi dari satu unit kompetensi harus dilakukan dengan hati-hati dan memperhatikan keluasan kompetensi yang harus dikuasai. 3. Stand Alone (berdiri sendiri); yaitu modul yang dikembangkan tidak tergantung pada media lain atau tidak harus digunakan bersama-sama dengan media pembelajaran lain sendiri. 4. Adaptive; modul hendaknya memiliki daya adaptif yang tinggi terhadap perkembangan ilmu dan teknologi. 5. User Friendly; modul hendaknya bersahabat dengan pemakainya.

Dalam penulisan modul terdapat tiga teknik menurut Sungkono, dkk.(2003) yaitu menulis sendiri, pengemasan kembali informasi dan penataan informasi. Dan masih diungkapkan Sungkono dkk bahwa komponen utama modul meliputi tinjauan mata pelajaran, pendahuluan, kegiatan belajar, latihan; ramburambu jawaban latihan, rangkuman, tes formatif, dan kunci jawaban tes formatif. 


\section{Kearifan Lokal (local wisdom)}

Dalam pengertian kamus, kearifan lokal (local wisdom) terdiri dari dua kata: kearifan (wisdom) dan lokal (local). Dalam Kamus Inggris Indonesia John M. Echols dan Hassan Syadily, local berarti setempat, sedangkan wisdom (kearifan) sama dengan kebijaksanaan. Secara umum maka local wisdom (kearifan setempat) dapat dipahami sebagai gagasan-gagasan setempat (local) yang bersifat bijaksana penuh kearifan, bernilai baik, yang tertanam dan diikuti oleh anggota masyarakatnya.

Secara umum, kearifan lokal (dalam situs Departemen Sosial RI) dianggap pandangan hidup dan ilmu pengetahuan serta berbagai strateg kehidupan yang berwujud aktivitas yang dilakukan oleh masyarakat lokal dalam menjawab berbagai masalah dalam pemenuhan kebutuhan mereka. Kearifan lokal bukan sekedar nilai tradisi atau ciri lokalitas semata melainkan nilai tradisi yang mempunyai daya-guna untuk untuk mewujudkan harapan atau nilai-nilai kemapanan yang juga secara universal yang didamba-damba oleh manusia namun juga pengetahuan yang dikembangkan oleh para leluhur dalam mensiasat lingkungan hidup sekitar mereka, menjadikan pengetahuan itu sebagai bagian dari budaya dan memperkenalkan serta meneruskan itu dari generasi ke generasi. Kearifan lokal yang berwujud nyata, antara lain;1). Tekstual, contohnya yang ada tertuang dalam kitab kono (primbon), kalinder. 2). Tangible, contohnya bangunan yang mencerminkan kearifan lokal. 3). Candi Borobodur, batik dan lain-lain.

Pendidikan berbasis kearifan lokal sejalan dengan pandangan Coombs (1968) yang melihat pendidikan merupakan suatu proses yang berinteraksi dengan lingkungannya. Output yang ingin dihasilkan dari suatu sistem pendidikan ditentukan oleh tujuan yang dikehendaki oleh lingkungan atau masyarakat. Manusia yang terdidik hendaknya diperlengkapi untuk melayani masyarakat dan mengurus dirinya sendiri sebagai individu dan anggota masyarakat, pekerja ekonomi, pemimpin dan inovator, warga negara dan warga dunia dan penyumbang kebudayaan. Untuk itu, pendidikan harus mampu meningkatkan basic knowledge (pengetahuan dasar) intellectual and manual skills (keterampilan manual dan intelektual); power of reason critism (daya nalar/kritik); values, attitudes and motivation (nilai-nilai, sikap dan motivasi); power of creativity and innovation (daya kreatif dan inovasi); cultural appreciation (apresiasi kebudayaan); sense of social responsibillity (tanggung jawab sosial); dan understanding of the moder world (memahami dunia modern).(Diunduh dari http://sosbud.kompasiana.com/ 2010/07/14/pendidikan-berbasis-kearifan-lokal)

\section{METODE PENELITIAN}

Pendekatan Penelitian

Penelitian ini merupakan penelitian dan pengembangan (Research and Development) bahan ajar, khususnya berupa pembelajaran melalui bahan ajar berupa modul untuk matakuliah Dasar-dasar Desain Seni Kerajinan. Modul ini merupakan produk pendukung dari bahan ajar lain yang telah ada baik cetak maupun non cetak.

Model pengembangan dalam penelitian ini mengacu pada rancangan model Borg and Gall (1983). Model ini sangat tepat digunakan untuk penelitian pengembangan yang menghasilkan produk.

Adapun langkah-langkah yang akan dilampaui dalam penelitian ini adalah:

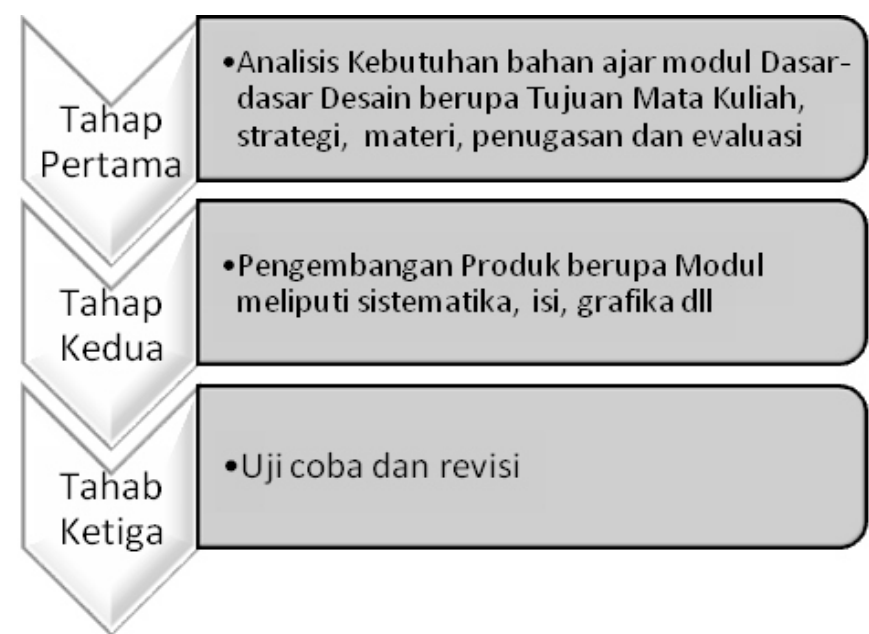

Gambar 1. Bagan Langkah Penelitian

Secara rinci langkah yang telah dilakukan dalam penelitian ini yaitu:

a. Melakukan penelitian awal dengan melakukan identifikasi kebutuhan pengembangan produk bahan ajar Dasar-dasar Desain melalui kajian pustaka dan pengamatan kelas

b. Melakukan perencanaan membuat analisis kebutuhan (silabus, tujuan pembelajaran, menentukan urutan materi)

c. Melakukan diskusi dalam kegiatan FGD untuk menyiapkan materi yang tepat

d. Mengembangkan bentuk produk awal

e. Melakukan uji coba produk pada ahli

f. Melakukan revisi produk

g. Melakukan uji coba produk pada pengguna

Melakukan revisi produk akhir. 


\section{Rancangan Penelitian}

Penelitian pengembangan ini bertujuan menghasilkan produk berupa modul. Dan dalam kegiatan penelitian dilakukan uji coba dari sisi materi dan sisi media, sehingga dalam penelitian ini melibatkan ahli materi dan ahli media untuk memberikan validasi terhadap produk yang sudah dibuat. Selain itu, modul juga diuji cobakan pada pengguna terbatas dan melibatkan mahasiswa sebagai validatornya. Dalam melakukan validasi modul ini ada beberapa kegiatan penilitian, yaitu:

a. Proses produksi bahan ajar berupa modul

Dalam tahap ini terdapat beberapa kegiatan:

1) Analisis kebutuhan

Kegiatan analisis kebutuhan dilakukan melalui kegiatan focus group discussion yang diikuti oleh 5 dosen yang memiliki kompetensi di bidang media pembelajaran dan materi pembelajaran Dasar-dasar Desain.

2) Seleksi materi

Seleksi materi dilakukan untuk memilih kompetensi yang tepat disajikan dalam modul.

3) Pembuatan draf modul

4) Pembuatan Modul

b. Uji ahli, baik dari sisi materi maupun media. Uji ahli modul Dasar-dasar Desain ini melibatkan 3 orang ahli yaitu, 2 orang ahli materi dan 1 orang ahli media.

c. Uji pengguna terbatas yang terdiri dari 5 mahasiswa yang terdiri dari 2 mahasiswa semester 1 dan 3 mahasiswa semester 5 .

d. Revisi modul Dasar-dasar Desain berdasarkan masukan dari ahli materi, ahli media maupun para pengguna.

e. Finalisasi produk modul setelah melalui beberapa proses diatas.

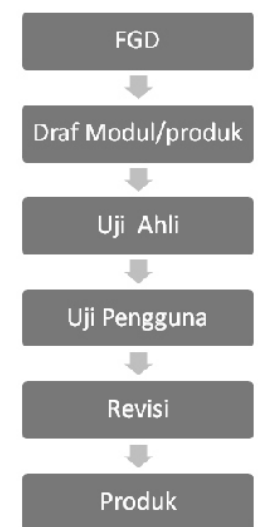

Gambar 2. Skema Rancangan Penelitian

\section{Subjek Penelitian}

Subjek penelitian ini melibatkan subjek ahli yang berkompeten di bidangnya dan mahasiswa sebagai pengguna modul.

a. Subjek ahli

Subjek ahli terdiri dari ahli materi dan ahli media yang berkompeten dalam materi Dasar-dasar Desain serta media. Subjek penelitian dipilih dengan menggunakan teknik purposive dengan kriteria

1) Pendidikan $S 2$ untuk bidang terkait

2) Berpengalaman di bidangnya minimal 5 tahun

3) Bersedia menjadi subjek ahli

b. Mahasiswa

Subjek penelitian pengguna terdiri dari mahasiswa pengguna produk penelitian ini. Pengambilan subjek penelitian ini menggunakan teknik random. Mahasiswa yang dilibatkan dalam proses validasi terdiri dari 2 mahasiswa yaitu mahasiswa semester 3 yang belum menempuh mata kuliah Dasar-dasar Desain dan 3 mahasiswa semester 7 yang telah lulus mata kuliah Dasar-dasar Desain.

\section{Variabel Penelitian}

Variabel penelitian yang manjadi focus pada penelitian ini adalah penilaian terhadap isi dan penyajian modul Dasar-dasar Desain yang berupa modul cetak.

a. Penilaian Kelayakan Isi

Merupakan variable yang berupa skor terhadap isi materi pembelajaran yang disajikan.

b. Penilaian Penyajian

Merupakan penilaian terhadap bentuk penyajian dari modul

c. Penilaian Tampilan

Merupakan penilaian terhadap tampilan secara grafika dan tampilan media.

Penilaian terhadap tampilan, isi dan penyajian ini dikategorikan menjadi empat, yaitu sangat baik, baik, cukup dan kurang. Adapun kriteria penilaian tersebut adalah sebagai berikut:

a. Penilaian sangat baik, apabila $100 \%$ telah sesuai dan tepat

b. Penilaian baik, apabila $75 \%$ telah sesuai dan tepat

c. Penilaian sedang, apabila $50 \%$ telah sesuai dan tepat

d. Penilaian kurang, apabila dibawah $25 \%$ kesesuaiannya

\section{Instrumen Penelitian}

Data validasi modul diperoleh dengan menggunakan skala penilaian terhadap isi dan penyajian modul Dasar-dasar Desain. Angket penilaian modul 
untuk ahli media terdiri dari beberapa komponen yaitu kelayakan isi, penyajian dan tampilan

\section{Analisis Data}

Data penelitian ini merupakan data hasil eksploratif. Data penelitian yang telah terkumpul kemudian dianalisis dengan deskriptif kuantitatif teknik prosentase dan deskriptif kualitatif.

\section{HASILDAN PEMBAHASAN}

Hasil penelitian ini meliputi hasil kegiatan focus group discussion berupa masukan terhadap persiapan produk dan hasil uji ahli serta uji pengguna. Dalam uji ahli dan pengguna dilakukan dengan memberikan penilaian terdiri dari 4 kategori. Angka 1 berarti aspek yang dinilai kurang, angka 2 berarti sedang, angka 3 berarti baik dan angka 4 berarti sangat baik. Selanjutnya untuk mendapatkan prosentase hasil penelitian pengguna secara keseluruhan, peneliti merujuk pada pendapat Suharsimi Arikunto (1998) dengan rumus:

$$
\%=\frac{\text { Jumlah skor yang diperoleh per aspek }}{\text { Jumlah subjek x jumlah opsi penilaian }} \times 100 \%
$$

Setelah mendapat prosentase tersebut selanjutnya ditapsirkan ke dalam empat kategori dengan rujukan sebagai berikut:

$76 \%-100 \%=$ Baik

$51 \%-75 \%=$ Cukup Baik

$26 \%-50 \%=$ Kurang Baik

$0 \%-25 \%=$ Tidak baik

\section{Focus Group Discussion}

Kegiatan focus group discussion (FGD) dilakukan sebagai kegiatan pengembangan tahab awal. Kegiatan ini diikuti oleh 5 dosen yang memiliki pengalaman dan keahlian di bidang media pembelajaran, bahan ajar, metode pembelajaran, dan materi Dasar-dasar Desain.

Dalam kegiatan FGD juga dibahas mengenai bagaimana local wisdom diterapkan dalam pembelajaran Dasar-dasar Desain melalui tujuan pembelajaran sampai pada materi pembelajaran yang mengkaitkan dengan persoalan loca wisdom. Kegiatan FGD ini menjadi kegiatan awal pengembangan yang sangat penting agar tahab pengembangan berikutnya dapat berjalan dengan baik dan meminimalisasi kelemahan dari bahan ajar.

\section{Hasil Uji Ahl}

Penilaian komponen isi dan penyajian modul pembelajaran ini melibatkan ahli dari jurusan Pendidikan Seni Rupa. Terdiri dari 2 dosen yang memiliki pengalaman dalam pembelajaran dan materi Dasar-dasar Desain. Penilaian ini meliputi aspek kelayakan isi dan penyajian modul. Dari aspek kelayakan isi, ahli materi menilai baik (90\%) sebagai bahan ajar, sementara dari aspek penyajian juga menilai baik (95\%). Selanjutnya ahli juga memberikan komentar dan masukan. Modul sudah cukup memberi penjelas dan gambaran materi pada mahasiswa. Perlu ditambahkan penjelasan lebih lanjut terkait acuan pustaka di setiap sub babnya. Konsistensi sistematika perlu diperbaiki. Kekinian ilmu perlu ditingkatkan.

Penilai komponen tampilan adalah 1 orang ahli media dari latar belakang Desain Komunikasi Visual. Penilaian ini meliputi aspek tampilan. Dari aspek tampilan ahli media menilai baik $(90,6 \%)$ sebagai bahan ajar. Cover sudah bagus, tata letak perlu dibenahi agar lebih menarik bagi pembaca kalangan mahasiswa, tidak perlu terlalu formal. Keterkaitan teks dan ilustrasi supaya diperjelas. Tampilan penutup perlu dibuat lebih menarik.

\section{Hasil Uji Pengguna Terbatas}

Uji pengguna terbatas ini dilakukan dengan kelompok kecil yang terdiri dari 5 mahasiswa, 2 mahasiswa adalah mahasiswa semester 3 yang semester berikutnya akan mengambil mata kuliah Dasar-dasar Desain. Sedangkan 3 mahasiswa semester 7 yang pernah mengikuti kuliah Dasar-dasar Desain. Hasil uji pengguna menunjukkan dari komponen isi dinilai baik (92,5\%) dan dari komponen penyajian juga dinilai baik (95\%).

Dalam analisis kebutuhan ditemukan bahwa mahasiswa membutuhkan bahan ajar cetak yang berupa modul untuk memudahkan mereka dalam memahami materi dan mencari sumber acuan. Materi dalam modul dipilih materi yang mendukung pemahaman mahasiswa tentang Dasar-dasar Desain yang sifatnya mendasar. Oleh sebab itu dalam penelitian pengembangan ini dikembangkan bahan ajar berupa modul cetak.

Uji validasi terhadap modul Dasar-dasar Desain diawali dengan uji ahli yang melibatkan ahli materi dan ahli media. Berdasarkan ahli materi, modul Dasar-dasar Desain dari komponen isi secara umum dinilai baik, dan sudah dinyatakan baik. Hanya pada bagian acuan kepustakaan serta kedalaman materi perlu dilengkapi agar memudahkan mahasiswa untuk mencari rujukan lain yang mendukung serta memudahkan mahasiswa belajar mandiri. Pada aspek kelengkapan materi, dan kekinian ilmu juga perlu adanya penambahan agar modul bisa lebih menarik. Namun demikian, modul Dasar-dasar Desain dinilai layak untuk diproduksi tanpa revisi 
Hasil uji validasi oleh ahli media secara umum juga dinyatakan baik. Terdapat beberapa bagian yang perlu diperbaiki antara lain layout disarankan untuk dengan lay out yang tidak terlalu formal agar modul berkesan ringan untuk dibaca. Dari sisi tampilan gambar ilustrasi dalam editing supaya lebih detail lagi agar tampilan gambar dapat lebih jelas.. Hasil uji ahli media menyatakan bahwa modul Dasar-dasar Desain dinilai baik dan layak digunakan sebagai bahan ajar.

Pada uji pengguna yang terdiri dari 5 mahasiswa secara umum modul

Dasar-dasar Desain dinilai baik dengan hasil penilaian terhadap kelayakan is 92,5\% dan dari segi penyajian 95\%. Berdasarkan analisis terhadap beberapa aspek yang masih dinilai rendah antara lain masalah kejelasan bahasa perlu dibedakan beberapa penjelasan pada beberapa sub bagian dengan detail. Tentang kekinian ilmu juga perlu ditingkatkan serta aspek mendorong keingin tahuan pengguna perlu semakin dirangsang dengan memberikan penyajian materi yang lebih tepat.

\section{DAFTAR PUSTAKA}

Gall, M.D, JP \& Borg, W R, 2003, Educational Research. An Introduction. Arlington Street, Boston: Pearson Education, Inc.

Santyasa, I Wayan, Metode Pengembangan dan Teori Pengembangan Modul. http://www.freewebs.com/santyasa/pdf2/METODE_PENELITIAN.pdf diakses 12 Maret 2012.

Setyosari, Punaji, 2010. Metode Penelitian Pendidikan dan Pengembangan. Kencana Prenada, Jakarta.

Sungkono, dkk. 2003. Pengembangan Bahan Ajar. Yogyakarta: FIP UNY.

Vembiranto, St. 1985. Pengantar Pengajaran Modul. Yogyakarta: Yayasan Pendidikan Paramita.

Van Peursen. 1976. Strategi Kebudayaan. Kanisius, Yogyakarta.

Sartini. 2000. Menggali Kearifan Lokal Nusantara Sebuah Kajian Filsafati. http://jurnal.filsafat.ugm.ac.id/index.php/jf/article/viewFile/45/41 
